\title{
A novel uterine protein that associates with the embryonic capsule in equids
}

\author{
F. Stewart ${ }^{1,2}$, B. Charleston ${ }^{2 *}$, B. Crossett ${ }^{1,2}$, P. J. Barker ${ }^{2}$ and \\ W. R. Allen ${ }^{1}$ \\ 'Thoroughbred Breeders' Association Equine Fertility Unit, Mertoun Paddocks, Woodditton Road, \\ Newmarket, Suffolk, CB8 9BH, UK; and ${ }^{2}$ The Babraham Institute, Babraham Hall, \\ Cambridge CB2 4AT, UK
}

\begin{abstract}
An apparently unique protein produced in large quantities by the endometrium of the mare which adheres to, or is incorporated into, the acellular capsule that surrounds the equine conceptus in early pregnancy, has been characterized and partially sequenced. It has a molecular mass of approximately $18 \mathrm{kDa}$ on SDS-PAGE gels and is nonglycosylated as assessed by a sensitive carbohydrate detection kit. Comparison of its first 24 amino-terminal amino acids with all entries in the databases failed to show any significant identity with any other protein sequence. Secretion of the protein appears to be progesterone dependent, as its presence in uterine flushings correlates with peripheral serum progesterone profiles during the oestrous cycle and its secretion can be induced in anoestrous mares by administration of a synthetic progestagen. However, in pregnant mares, the protein disappears from the uterus after about day 20 (term $=320-340$ days), despite the persistence of high serum concentrations of progesterone, indicating that additional mechanisms control its synthesis and secretion. The strong association of the protein with the glycoprotein capsule that surrounds the equine blastocyst suggests that it may be incorporated into the capsule as the capsule expands from day 11 after ovulation. Alternatively, or additionally, it may be involved in the transport of nutrients or other substances through the capsule, and may therefore play an important role in the maintenance of pregnancy.
\end{abstract}

\section{Introduction}

Equine conceptuses do not begin to implant and form stable attachments to the endometrium until as late as 36 days after ovulation (Samuel et al., 1974) and, up to about day 22, are surrounded by an acellular glycoprotein capsule (Betteridge et al., 1982; Oriol et al., 1993a). They must therefore rely for sustenance on the absorption of endometrial gland secretions ('uterine milk'; Amoroso, 1952), for an exceptionally long period. Furthermore, until day 22, imbibition of this material must occur through the capsule. For this reason, preimplantation uterine secretions are probably more important for embryonic growth and the maintenance of pregnancy in equids than in the other large domestic animal species. In addition, the exact mechanism by which equine conceptuses are able to prevent luteolysis of the maternal corpus luteum is not known (Bazer et al., 1994). Since the first step during this process almost certainly involves an interaction between the conceptus and the maternal endometrium, it is important to examine uterine, as well as conceptus, secretions.

*Present address: Institute for Animal Health, Compton, Newbury, Berkshire RG16 ONN, UK.

Received 22 March 1995.
In the present study, we analysed proteins secreted in vitro by the extraembryonic membranes of young equine conceptuses and in vivo by the uteri of mares during the oestrous cycle and early pregnancy. Unexpectedly, a large amount of protein with an estimated molecular mass of $18 \mathrm{kDa}$ on SDS-PAGE gels was released into the culture medium during incubation of the acellular capsule, with or without the conceptus membranes, for 12-16 h. Subsequently, the protein was found to be secreted in large quantities into the lumen of the uterus in both pregnant and nonpregnant mares and this study describes its partial characterization and amino-terminal sequence.

\section{Materials and Methods}

\section{Animals and tissue recovery}

A total of 20 maiden and barren Thoroughbred mares aged 3-7 years was used. Their oestrous cycles were monitored by a combination of teasing with an active stallion for signs of behavioural oestrus and transrectal realtime ultrasound scanning of the ovaries to assess follicular development. Ovulation was diagnosed by measuring a rise in progesterone Downloaded from Bioscientifica.com at 04/26/2023 12:02:55PM 
concentrations in peripheral plasma samples recovered daily during and beyond oestrus. Day 1 of the cycle or pregnancy was taken as the first day on which values exceeded $1 \mathrm{ng}$ $\mathrm{ml}^{-1}$. Seasonal anoestrus was diagnosed ultrasonographically by a lack of follicular development in the ovaries during the winter months and confirmed by low $\left(<1 \mathrm{ng} \mathrm{ml}^{-1}\right)$ progesterone concentrations in three consecutive plasma samples recovered at intervals of 1 week.

Conceptuses were recovered nonsurgically from six pregnant mares on days 11,14,16, 18, 19 and 25 after ovulation, by lavage of the uterus with I litre sterile PBS via a $14 \mathrm{~mm}$ endotracheal tube passed through the cervix. Each conceptus was transferred immediately to serum-free Dulbecco's modified Eagle's medium (GIBCO-BRL, Paisley) containing antibiotics, insulin and nonessential amino acids, and incubated at $37^{\circ} \mathrm{C}$ in an atmosphere of $5 \% \mathrm{CO}_{2}$ in air for 12-16 h as described by Godkin et al. (1982) at a conceptus (g wet mass): medium (ml) ratio of approximately $1: 3$. The day 11 conceptus was the only one that did not rupture during the collection procedure and it was cultured intact. In addition, the embryo was removed from the day 25 conceptus before incubation, approximately $50 \%$ of the capsule surrounding the day 14 conceptus was removed and incubated alone, and approximately $50 \%$ of the membranes of the day 18 conceptus were removed and incubated without capsule. These separations were done to assess the relative contributions of the membranes and capsules to released and secreted proteins. At the end of the incubation period, the membranes, which had started to disintegrate, and the capsules, which were ruptured but intact, were removed. The medium was centrifuged at $1000 \mathrm{~g}$ for $2 \mathrm{~min}$ to remove cellular debris and stored at $-20^{\circ} \mathrm{C}$ until analysed. The day 14 half capsule that had been incubated alone, and the whole day 16 capsule, were each incubated alone in fresh medium for a further $24 \mathrm{~h}$ to determine whether the capsule released any more protein. The capsule material did not change in appearance, even after this second incubation.

\section{Uterine fluids}

In 14 other mares, during oestrus $(n=3)$, and at days 10 $(n=1), 12(n=2), 16(n=1)$ and $18(n=2)$ after ovulation during the oestrous cycle, and on days $7(n=1), 10(n=1)$, $12(n=2), 14(n=2), 18(n=3), 19(n=1)$ and $24(n=1)$ of pregnancy, $20 \mathrm{ml}$ sterile PBS was infused into the uterus via a catheter passed through the working channel of a videoendoscopic hysteroscope (Welch Allyn, Model 81200V; Seward Medical Company, London); some of the mares were used twice, once during the oestrous cycle and again during pregnancy. The uterus was massaged gently per rectum after which as much as possible of the fluid was recovered by directing the tip of the catheter into the pool of fluid on the uterine floor. These samples were stored at $-20^{\circ} \mathrm{C}$ until analysed.

The same uterine flushing procedure was carried out in four seasonally anoestrous mares, two of which were dosed orally with $40 \mathrm{mg}$ of the synthetic progestagen, allyl trenbolone (Regumate; Hoechst Animal Health UK Ltd, Herts) daily for 10 days before flushing.

\section{SDS-PAGE and amino acid sequencing}

The samples of culture medium in which conceptuses and capsules had been incubated, and the uterine flushings from pregnant, nonpregnant and anoestrous mares were subjected to one-dimensional SDS-PAGE on $1.5 \mathrm{~mm} 12 \%$ acrylamide gels. If required for photography, the gels were stained with $0.1 \%(\mathrm{w} / \mathrm{v})$ Coomassie blue in $10 \%(\mathrm{v} / \mathrm{v})$ methanol- $10 \%(\mathrm{v} / \mathrm{v})$ acetic acid and destained in $10 \%(\mathrm{v} / \mathrm{v})$ methanol- $-10 \%(\mathrm{v} / \mathrm{v})$ acetic acid. If required for isolation of the $18 \mathrm{kDa}$ protein for sequencing, the proteins were transferred to a polyvinylidene diflouride membrane (Problott; Applied Biosystems, Warrington) using a wet electroblotter (Trans-Blot cell; Bio-Rad Labs Ltd, Hemel Hempstead), lightly stained with $0.1 \%$ Coomassie blue in $50 \%(\mathrm{v} / \mathrm{v})$ methanol- $10 \%(\mathrm{v} / \mathrm{v})$ acetic acid, and the area of membrane containing the $18 \mathrm{kDa}$ protein was excised. Care was taken not to include any of the material showing a slightly higher electrophoretic mobility than the $18 \mathrm{kDa}$ protein. Amino-terminal sequencing was then carried out using a $470 \mathrm{~A}$ gas phase sequencer (Applied Biosystems) equipped with a $120 \mathrm{~A}$ on line phenylthiohydantoin analyser.

Approximately $I \mu \mathrm{g}$ total protein per track was loaded onto duplicate $12 \%$ acrylamide gels to test for glycosylation. One gel was stained with Coomassie blue in the usual way and the other was transferred to a Hybond $C$ nylon membrane (Amersham International, Amersham) and tested with a carbohydrate detection kit (GlycoTrack; Oxford Glycosystems, Oxford). The kit incorporates biotin into the carbohydrate moieties of the transferred proteins, which is then detected with a streptavidin-alkaline phosphatase conjugate; the limit of detection was $12.5 \mathrm{ng}$ of a glycoprotein containing $2 \%(\mathrm{w} / \mathrm{w})$ carbohydrate. A crude preparation of equine luteinizing hormone (LH; DEAE I; $0.45 \mathrm{mg}$ NIH.LH.SI $\mathrm{mg}^{-1}$; Anne Stockell-Hartree, Cambridge) was used as a positive control.

\section{Results}

\section{SDS-PAGE analyses}

The results of the one-dimensional electrophoretic analysis carried out on the incubates of conceptus membranes are shown in Fig. 1. A prominent band at approximately $18 \mathrm{kDa}$ was seen in the day 11, 14, 16 and 19 samples, all of which contained capsules (Fig. 1a). The day 11 conceptus was the only one cultured intact, which accounted for the much lower overall protein content in this sample. Nevertheless, the $18 \mathrm{kDa}$ protein was still visible. In contrast, there was so much of the $18 \mathrm{kDa}$ protein in the day 16 sample that the band appeared smeared and distorted. The capsule had already disintegrated from the day 25 conceptus and the $18 \mathrm{kDa}$ protein was not detectable in the incubate of this sample. The incubates of the day 14 capsule alone, the same capsule with its conceptus membranes, and the incubates of the day 18 conceptus membranes alone and with capsule, all show clearly that a large amount of the $18 \mathrm{kDa}$ protein was released into the culture medium only when the capsule was present. Furthermorc, the capsule alone released as much protein as did the Downloaded from Bioscientifica.com at 04/26/2023 12:02:55PM 

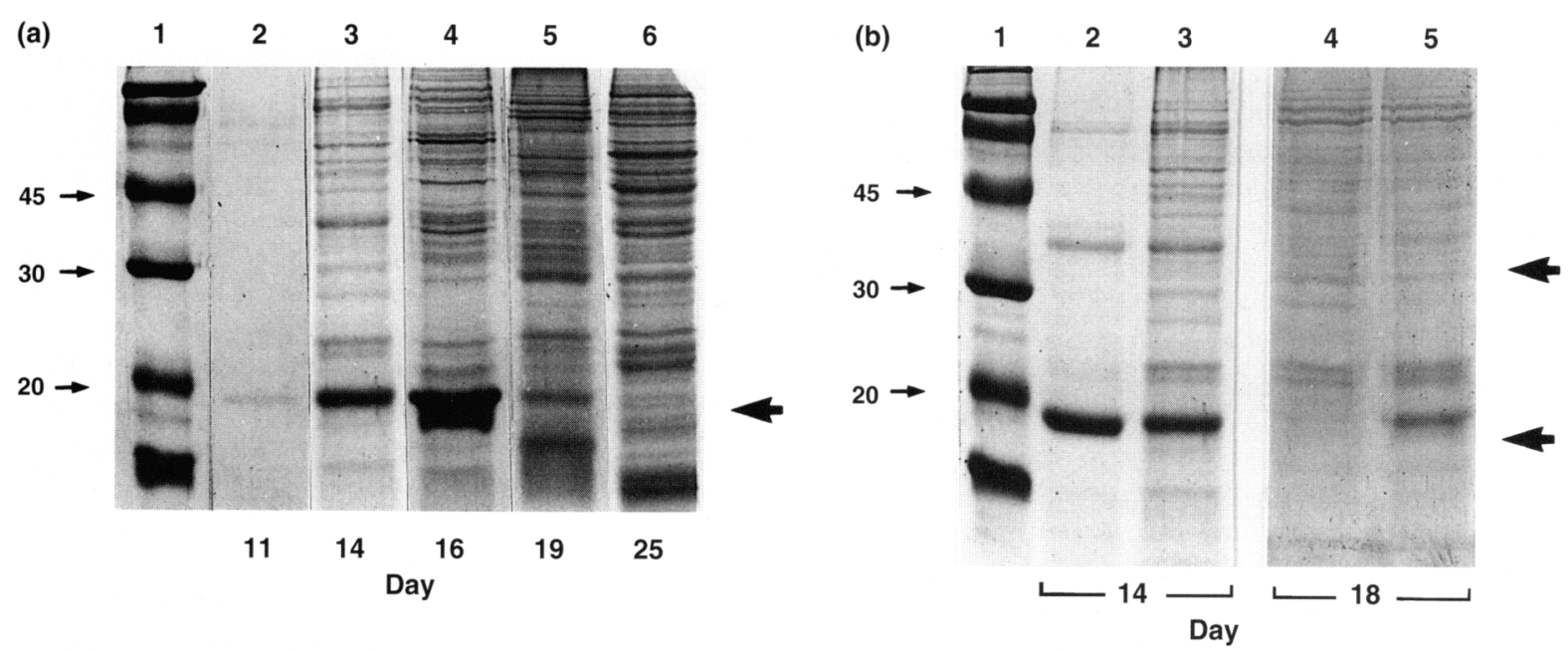

Fig. 1. Coomassie blue-stained SDS-PAGE gels of serum-free culture medium samples $(40 \mu \mathrm{l}$ aliquots) in which equine conceptuses had been incubated for 12-16 h. (a) Day 11 (lane 2), day 14 (lane 3), day 16 (lane 4), day 19 (lane 5) and day 25 (lane 6 ) conceptuses. The day 11 conceptus was the only one that remained intact inside its capsule during incubation, while the day 25 conceptus had already lost its capsule completely. Lane 1 shows molecular mass markers (in $\mathrm{kDa}$ ) and the arrow (on the right) indicates the position of the $18 \mathrm{kDa}$ protein (P18). (b) Day 14 conceptus capsule incubated alone (lane 2) and with conceptus membranes (lane 3), and day 18 conceptus membranes alone (lane 4) and with capsule (lane 5). Molecular mass markers are in lane 1 (in $\mathrm{kDa}$ ) and the arrows (on the right) indicate the position of the $18 \mathrm{kDa}$ protein and its possible $36 \mathrm{kDa}$ dimer. The amino terminus of the $18 \mathrm{kDa}$ protein (P18) purified from the day 18 conceptus was sequenced.

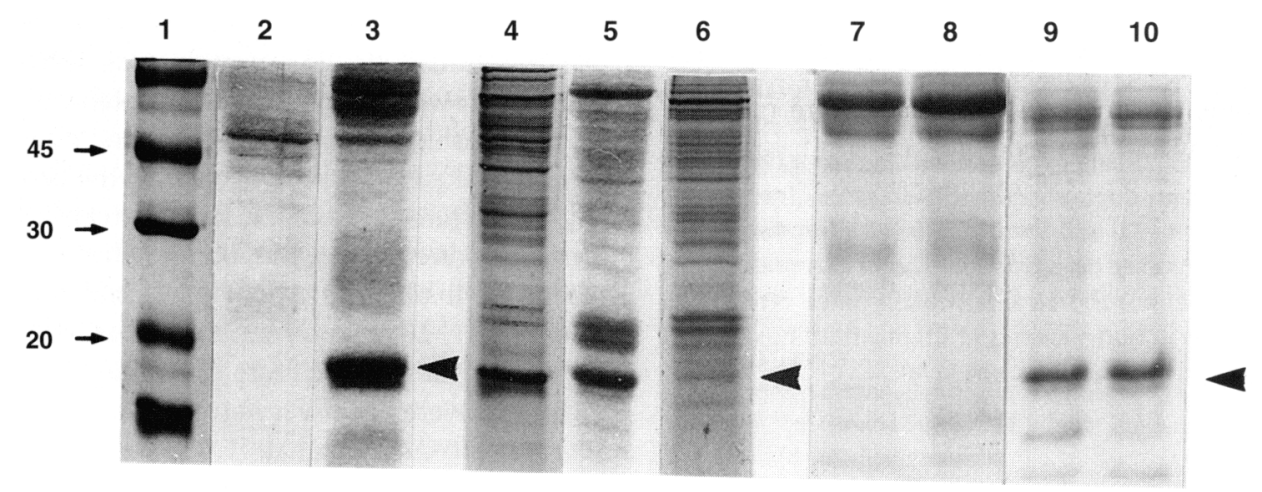

Fig. 2. Coomassie blue-stained SDS-PAGE analysis of uterine flushings ( $40 \mu \mathrm{l}$ aliquots) from cyclic nonpregnant (lanes 2 and 3), pregnant (lanes 4-6) and anoestrous (lanes 7-10) mares. Lane 1, molecular mass markers (in $\mathrm{kDa}$ ); lane 2, mare in oestrus; lane 3, mare at day 12 after ovulation; lanes 4,5 and 6 , mares at days 12,14 and 19 of pregnancy, respectively; lanes 7 and 8, two mares in anoestrus; lanes 9 and 10 , two anoestrous mares given $40 \mathrm{mg}$ allyl trenbolone daily for 10 days before flushing. Large arrowheads indicate the position of the $18 \mathrm{kDa}$ protein (P18), which was purified from the day 12 nonpregnant mare (lane 3) and day 14 pregnant mare (lane 5) gels and the amino terminus sequenced. All of the samples containing P18 also had a small amount of an additional protein with a slightly higher electrophoretic mobility. The amount of this protein appeared to be proportional to the amount of P18, and could represent a variant of P18.

whole conceptus, including the capsule (Fig. 1b). The day 14 and day 16 capsules incubated in fresh medium for a further $24 \mathrm{~h}$ released approximately the same amount of $18 \mathrm{kDa}$ protein as they had done during the initial $12-16 \mathrm{~h}$ incubation (results not shown). In addition, a $36 \mathrm{kDa}$ protein appeared to be associated with the $18 \mathrm{kDa}$ protein (see Fig. Ib), suggesting possible dimerization of the $18 \mathrm{kDa}$ protein.

The gel analysis of the uterine flushings is summarized in Fig. 2. The samples taken from the three mares in oestrus were very similar in appearance and all failed to show an $18 \mathrm{kDa}$ protein band (lane 2). The protein first became visible by day 10 after ovulation, appeared to peak at about day 12 (one of the two samples from day 12 shown in lane 3 ), and became undetectable again by day 18 , when the mare was returning to oestrus. In pregnant mares, the protein was again first seen in the uterine flushing at day 10 (not shown); it peaked at days 12-14 (lanes 4 and 5), was still just visible at day 19 (lane 6) but had disappeared by day 24 (not shown). The two samples 


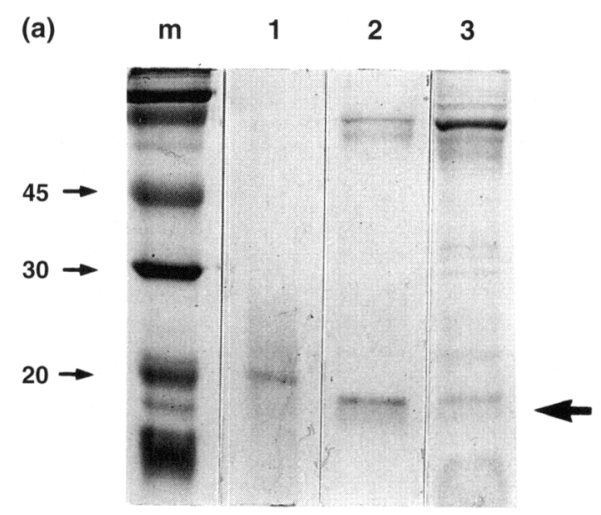

(b)

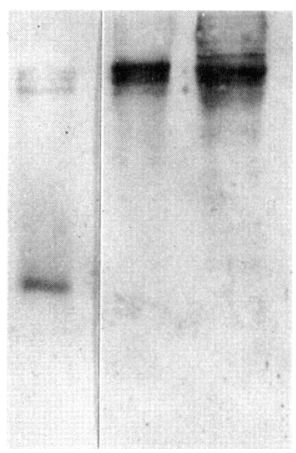

Fig. 3. Carbohydrate detection kit analysis of endometrial proteins from two mares (lanes 2 and 3). Approximately $I \mu \mathrm{g}$ total protein aliquots (lane 1, crude preparation of $\mathrm{LH}$; lane 2, uterine flushing from the day 12 pregnant mare and lane 3, uterine flushing from the day 18 pregnant mare) were run on duplicate SDS-PAGE gels. One gel was stained with Coomassie blue (a) and the other (b) was transferred and analysed with the carbohydrate detection kit. The LH sample (lane 1) was carbohydrate-positive, but the $18 \mathrm{kDa}$ protein (large arrow) was negative for carbohydrate in both samples of uterine flushings (lanes 2 and 3). $\mathrm{m}$, molecular mass markers (sizes in $\mathrm{kDa}$ ).

taken on day 12 gave very similar bands on the gel, as did the three samples taken on day 14. Although the small number of samples at each time point did not permit statistical analysis between animals or between the cycle and pregnancy, it was, nevertheless, possible to conclude that the pattern of secretion after ovulation was similar in pregnant and nonpregnant mares, but that secretion persisted for several days longer in the pregnant animals. Samples from both the anoestrous mares were negative (lanes 7 and 8), but those from the anoestrous mares given allyl trenbolone for 10 days before flushing (lanes 9 and 10) were both strongly positive. All of the uterine flushings that contained the $18 \mathrm{kDa}$ protein also showed a small amount of another protein with a slightly higher electrophoretic mobility (see Fig. 2). This band was not evident in any of the culture medium samples (see Fig. 1).

The results of the glycosylation test on two samples of uterine flushings are shown in Fig. 3. Whereas the equine LH (lane 1) was clearly positive, both uterine flushings containing the $18 \mathrm{kDa}$ protein (lanes 2 and 3) were negative, indicating that the $18 \mathrm{kDa}$ protein contains $<2 \%$ carbohydrate.
110

Leu-His-Met-Gly-Pro-Gly-Asp-Pro-Asn-Phe-

11

20

Asp-Glu-Lys-Leu-Val-Lys-Gly-Lys-Trp-Phe-

21

Ser-Val-Ala-Leu

Fig. 4. Amino-terminal sequence (1-24) of the $18 \mathrm{kDa}$ protein $(\mathrm{P} 18)$ isolated from the day 18 equine embryonic capsule and from the uteri of a day 14 pregnant and a day 12 nonpregnant mare. The sequence shows no significant identity or homology to any other protein in the databases.

\section{Amino acid sequencing}

The first sample of $18 \mathrm{kDa}$ protein to be sequenced was isolated from the culture medium in which the day 18 conceptus had been incubated (see Fig. 1). It produced a sequence of 20 residues ( $1-20$ in Fig. 4). The primary signal was very strong, without any ambiguities, consistent with the very strong and clear band obtained with Coomassie blue staining. There was also a faint secondary signal, which appeared to be one residue out-of-phase with the primary signal. This suggested the presence of a small amount of material that did not contain the amino-terminal Leu residue. At this stage, and owing to its clear association with the blastocyst capsule, the protein was thought to be fetal in origin. However, the $18 \mathrm{kDa}$ protein band present in the uterine flushings of both pregnant and nonpregnant mares (see Fig. 2) looked remarkably similar to the protein band produced by the cultured conceptus. For this reason, the $18 \mathrm{kDa}$ protein was recovered from the uterine flush of the day 12 nonpregnant mare (lane 3 in Fig. 2) and sequenced. It gave an identical 1-20 amino-terminal sequence to the material recovered from the culture medium. The signals from this sequence were again very strong and clear, and this time there was no secondary signal.

The identity of the protein produced during pregnancy was confirmed and the sequence was extended by purifying a sample from the uterine flushing from the day 14 pregnant mare (lane 5 in Fig. 2) and sequencing it. The first 20 residues were again identical to the original sequence obtained from the culture incubate and this time, a further four residues were obtained (see Fig. 4). Thus, it was possible to conclude that the protein is maternal in origin and is present in both pregnant and nonpregnant mares.

\section{Discussion}

Since the amino-terminal sequence of the $18 \mathrm{kDa}$ protein (P18) obtained from an incubate of a day 18 embryonic capsule was identical to the sequence of the material isolated from the uteri of a pregnant and a nonpregnant mare, it is clear that the protein is maternal in origin and that it binds to, or is incorporated into, the capsule. Furthermore, the clear correlation between its presence in the uterine lumen and the luteal phase of the oestrous cycle suggests a strong association with the cyclical pattern of progesterone secretion in the cyclic 
mare. Typically, progesterone concentrations are undetectable during oestrus, rise steeply after ovulation, remain high between days 5 and 14, fall steeply between days 14 and 16 and become undetectable again $\left(<1 \mathrm{ng} \mathrm{ml}^{-1}\right)$ by day 18 when the mare has usually returned to oestrus (Allen and Sanderson, 1987).

Previous studies that involved incubations of equine conceptus membranes (Sharp et al., 1989; McDowell et al., 1990) did not describe P18, presumably because they used incorporation of $\left[{ }^{3} \mathrm{H}\right]$ amino acids in the protocol, and so only visualized newly synthesized proteins. In addition, they discarded the capsule before incubation of the choriovitelline tissues. However, it is possible to compare the results of the present protein analyses of uterine flushings to the experiments of Zavy et al. (1982), Hinrichs et al. (1989) and McDowell et al. (1990), and it is very likely that the $17 \mathrm{kDa}$ basic protein ( $\mathrm{U}_{\mathrm{t}}$ ) described by Zavy et al. (1982) and Hinrichs et al. (1989) was P18. As well as being essentially the same size, $U_{1}$ showed evidence of dimer formation $\left(\mathrm{S}_{2}\right)$ and the presence of a smaller variant $\left(\mathrm{U}_{2}\right)$, similar to our observations on P18. However, while Hinrichs et al. (1989) showed induction of $U_{1}$ secretion in ovariectomized mares by the administration of exogenous progesterone, Zavy et al. (1982) did not. Our induction of P18 secretion in anoestrous mares by allyl trenbolone treatment is therefore consistent with that of Hinrichs ef al. (1989). Zavy et al. (1982) also described the secretion of $U_{1}$ during the oestrous cycle and pregnancy, and their results correlate well with the present study on P18, in that $U_{1}$ was secreted during the luteal phase of the cycle and was maintained during pregnancy until at least day 20.

The amino-terminal 24 amino acid sequence of P18 does not share significant identity with any protein sequences currently in the databases. It is therefore difficult to speculate about its biological actions in mares. However, the fact that its secretion into the uterine lumen during pregnancy coincides precisely with the development and regression of the embryonic capsule (Betteridge ef al., 1982; Oriol et al., 1993b), and its strong association with the capsule when the conceptus is still moving throughout the uterine lumen (Ginther, 1983), suggests two possibilities. First, P18 could act as a nutrient for the developing embryo. It may, for example, be necessary to transport vital components of 'uterine milk' through the capsule. However, it is not uteroferrin, which carries iron to the fetus, or retinolbinding protein, both of which have been described in the mare by McDowell et al. (1982, 1995). The finding that PI8 is nonglycosylated, as assessed by a carbohydrate detection kit, was unexpected, since most secreted endometrial proteins are glycosylated (Aplin, 1991).

A second possible function for P18 is as a component of the embryonic capsule. Our incubation experiments suggest that the association of P18 with the capsule involves a strong interaction and it is possible that the protein may become an integral part of the capsule. Bousquet et al. (1987) first noted the possibility of a maternal component of the capsule when they observed that the binding of an anti-capsule-serum to the capsule could be inhibited by prior absorption of the antiserum with lyophylized uterine flushings. Furthermore, since this was observed with flushings obtained from pregnant or nonpregnant mares 12.5 days after ovulation, but not with flushings obtained from pregnant mares 7.5 or 8.5 days after ovulation, it is highly likely that the anti-capsule-serum was directed, at least partially, against P18. Immunostaining with this antiserum was patchy and localized to the inner and outer surfaces of the capsule, rather than between them. In addition, Oriol et al. (1993a, b) demonstrated that, although the embryonic capsule is secreted initially by the trophectoderm and is composed basically of mucin-like glycoproteins, it is bilayered when analysed by lectin histochemistry and it increases by almost twenty times in mass between day 12 and day 18 after ovulation. Both of these observations suggest possible incorporation of maternal components at the later stage of capsule development.

Clearly, further studies are required to determine the exact origin and function of this unusual equine protein, which is secreted in large quantities during the luteal phase of the oestrous cycle, and until about day 20 of pregnancy. Work is underway to determine the full amino acid sequence and sites of expression of the protein. It would be valuable to examine the uterine flushings and secretions of other species, particularly those with blastocyst capsules (see Betteridge, 1989), for homologues of this protein.

The project was supported by The Horserace Betting Levy Board (Project 609) and The Thoroughbred Breeders' Association of Great Britain.

\section{References}

Allen WR and Sanderson MW (1987) The value of a rapid progesterone assay (AELIA) in equine and veterinary medicine and management. In Proceedings 9th Bain-Fallon Memorial Lectures pp 75-82 Ed. P Huntington. AEVA, Sydney

Amoroso EC (1952) Placentation. In Marshall's Physiology of Reproduction Vol. 2 pp 127-311 Ed. AS Parkes. Longmans, London

Aplin ID (1991) Glycans as biochemical markers of human endometrial secretory differentiation Journal of Reproduction and Fertility 91 525-541

Bazer FW, Ott TL and Spencer TE (1994) Pregnancy recognition in ruminants, pigs and horses: signals from the trophoblast Theriogenology 41 79-94

Betteridge KJ (1989) The structure and function of the equine capsule in relation to embryo manipulation and transfer Equine Veterinary Journal Supplement 8 92-100

Betteridge KJ, Eaglesome MD, Mitchell D, Flood PF and Bériault P (1982) Development of horse embryos up to twenty-two days after ovulation: observations on fresh specimens Journal of Anatomy 135 191-209

Bousquet D, Guillomot M and Betteridge KJ (1987) Equine zona pellucida and capsule: some physicochemical and antigenic properties Gamete Research 16 $121-132$

Ginther OJ (1983) Mobility of the equine conceptus Theriogenology 19 $603-611$

Godkin JD, Bazer FW, Moffat J, Sessions F and Roberts RM (1982) Purification and properties of a major, low molecular weight protein released by the trophoblast of sheep blastocysts at day 13-21 Journal of Reproduction and Fertility 65 141-150

Hinrichs K, Kenney RM and Sharp DC (1989) Differences in protein content of uterine fluid related to duration of progesterone treatment in ovariectomized mares used as embryo recipients Equine Veterinary Journal Supplement 8 49-55

McDowell KJ, Sharp DC, Fazleabas A, Roberts RM and Bazer FW (1982) Partial characterisation of the equine uteroferrin-like protein Journal of Reproduction and Fertility Supplement 32 329-334

McDowell KJ, Sharp DC, Fazleabas AT and Roberts RM (1990) Two dimensional polyacrylamide gel electrophoresis of proteins synthesized and released by conceptuses and endometria from pony mares Journal of Reproduction and Fertility 89 107-115 
McDowell KJ, Adams MH, Franklin KM and Baker CB (1995) Changes in equine endometrial retinol-binding protein RNA during the estrous cycle and early pregnancy and with exogenous steroids Biology of Reproduction $\mathbf{5 2}$ 438-443

Oriol JG, Betteridge KJ, Clarke AJ and Sharom FJ (1993a) Mucin-like glycoproteins in the equine embryonic capsule Molecular Reproduction and Development $34255-265$

Oriol JG, Sharom FJ and Betteridge KJ (1993b) Developmentally regulated changes in the glycoproteins of the equine embryonic capsule Journal of Reproduction and Fertility $99653-664$
Samuel CA, Allen WR and Steven DH (1974) Studies on the equine placenta. I. Development of the microcotyledons Journal of Reproduction and Fertility $\mathbf{4 1}$ 441-445

Sharp DC, McDowell KJ, Weithenauer K, Franklin K, Mirando M and Bazer FW (1989) Is an interferon-like protein involved in the maternal recognition of pregnancy in mares? Equine Veterinary Journal Supplement 8 7-9

Zavy MT, Sharp DC, Bazer FW, Fazleabas A, Sessions F and Roberts RM (1982) Identification of stage-specific and hormonally induced polypeptides in the uterine secretions of the mare during the oestrous cycle and pregnancy Journal of Reproduction and Fertility 64 199-207 